Валерий Л. Васильев

Новгородский гос.

университет им.

Ярослава Мудрого
UDK 81'373.21(470):811.17

DOI: 10.4312/linguistica.55.1.173-186

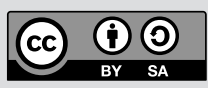

\title{
ПРОБЛЕМАТИКА ИЗУЧЕНИЯ ГИДРОНИМИИ БАЛТИЙСКОГО ПРОИСХОЖДЕНИЯ НА ТЕРРИТОРИИ РОССИИ
}

Названия рек и озер, сохраняющие остатки древних языков, остаются главным и зачастую единственным источником изучения этноязыковых ареалов, сложившихся в дописьменные эпохи. Древние народы отождествляются прежде всего с языком (даже если от этого языка остается всего лишь один единственный этноним) и открываются в языке (ср. показательное тождество др.-рус. языкъ 'язык' и 'народ'). Археологические изыскания, открывающие ареалы беззвучных, «немых» материальных культур далекого прошлого, в данном отношении второстепенны, подчинены лингвистическим изысканиям. Тезис о приоритетности гидронимии в полной мере применим к изучению древнебалтийского языкового наследия на современной территории проживания славян. В данной статье мы сосредоточимся на собственно русской территории, а именно на регионах Европейской России (отдельно от смежных областей Украины и Белоруссии), которые тысячу и более лет назад были заселены балтами.

Ни один из русских регионов никогда не рассматривался в качестве даже гипотетического пространства прародины славян (в отличие, например, от украинско-белорусского Среднего Поднепровья и правобережья Припяти). Сегодня устоялась обоснованная концепция о том, что восточные славяне начали заселять будущие русские земли Поочья, Верхнего Поволжья, Ильмень-Волховского и Чудско-Псковского бассейнов не ранее второй половины І тыс. н. э. - уже после распада праславянского единства в VI в. На этих землях западной части Европейской России (т. н. средняя полоса России) пришельцы-славяне встретились с автохтонным населением трех главных этноязыковых групп: балтоязычные племена в центральной части среднерусской полосы, тюркоязычные народы к югу от балтов в зоне степей (булгары, хазары, сменившие там ираноязычных скифов и сарматов), европейско-финские народности к северу от балтов (прибалтийские финны) и к северо-востоку и востоку от балтов (волжские финны). За прошедшие 1300-1500 лет в среднерусской полосе славяне полностью ассимилировали всех балтов, прибалтийских финнов и большую часть волжских финнов, равно как освоили полосу южнорусских степей, тюрки-кочевники из которых «растворились» среди других народов.

* 173003 Новгородский государственный университет имени Ярослава Мудрого, ул. Большая Санкт-Петербургская, д. 41, Великий Новгород, Россия; vihnn@mail.ru 
Изложенный общий взгляд на этноисторические события в указанном хронотопе, преобладающий сегодня в научном сообществе, утвердился сравнительно недавно. Историки и языковеды, опиравшиеся по преимуществу на древнерусские летописи и акты, либо вовсе не видели доисторического балтийского языкового элемента в Центральной России, либо совершенно недооценивали его, сводя все к поздним «литовским» следам или к летописной голяди. Начиная с историков конца XVIII-XIX в. (Татищева, Карамзина, Ключевского, Соловьева), традиционно больше внимания уделялось финскому элементу, о котором русская письменность сохранила множество разнообразных свидетельств и носители которого до сих пор живут на Русском Севере и в Среднем Поволжье. «Обыкновенно думают, что русские прибыли в свои древние поселения тогда, когда там жили финские племена, и заняли их, вытеснив, истребив, ассимилировав с собою финнов», писал А. И. Соболевский (1924: 274). О вкладе же давно исчезнувших «русских» балтов появилась возможность говорить лишь тогда, когда географические названия смогли по достоинству оценить как важный исторический источник. Только опора на гидронимию позволила в должной мере уяснить древнебалтийское присутствие на русской территории, причем благодаря обнаружению все новых и новых гидронимических балтизмов, предполагаемый ареал «русских» балтов в трудах исследователей постепенно уплотнялся и постепенно расширялся к востоку, северу и отчасти к югу. Изучение лексических, апеллятивных балтизмов-заимствований в русском языке (из последних работ на эту тему см. Аникин 2005; Аникин 2014) в отношении древних этноязыковых ареалов дает очень обобщенную, «смазанную» картину, поскольку апеллятивы, в отличие от географических имен, обычно не прикреплены к точечным локусам. Кроме того, в русском языке апеллятивные балтизмы в подавляющем большинстве датируют временем не ранее XIII в. (не ранее эпохи Великого Княжества Литовского), более древних правдоподобных балтизмов (дёготь, дере́вня, клеть, диал. а́лес 'топкое, сырое место', перть 'баня', му́ма 'страшило', 'вошь', пу́сма 'пук, связка' и др.) очень мало (Аникин 2014: 192).

Первым опытом изучения древней «русской Балтии» стала книга А. Л. Погодина (1901), в которой автор пишет о распространении балтийских племен в бассейне р. Оки, отмечая отдельные очевидные речные имена, оставленные ими в Поочье (Уnа, Жиздра, Нара и др.). В 1923 г. К. Буга, исследовав немало литовских, белорусских и смоленских названий водоемов, пришел к выводу, что к началу восточнославянского расселения в VI в. н. э. балты (литовцы) занимали всю Белоруссию и сопредельную русскую территорию Смоленщины (верховья Днепра и Сожи), тогда как земли восточнее Белоруссии и Смоленщины были заняты мордвой - волжскими финнами (Buga 1923; Buga RR III: 493-550). A. И. Соболевский, опираясь в основном на сообщения древнерусских летописей, продлил пространство балтов от Белоруссии до Москвы. Вместе с тем он считал балтийское население в русских землях (восточную литву и голядь) сравнительно поздним; ошибочно анализируя гидронимы, он видит автохтонным населением среднерусской полосы, которое предшествовало восточным славянам, 
не финнов, не балтов, а иранцев (скифов или сарматоскифов), распространявшихся с причерноморских степей в лесную полосу вплоть до Русского Севера (Соболевский 1924: 274-275). В начале 1930-х гг. М. Фасмер, на основе убедительной этимологизации нескольких десятков речных имен (Лучеса, Водва, Угра, Жезмянка, Можайка, Истра, Вержа, Жукопа, Панея, Лемна, Желемья, Скобра, Дугна, Квань, Лоба, Скальба, Титва, Окча, Сороть и др.), впервые доказал наличие заметного балтийского слоя, предшествовавшего славянскому, в центральных регионах России - в Смоленской, Псковской, Калужской, Московской, Орловской губерниях. Северная граница этого слоя была им проведена не севернее верхнего течения Волги, южная - примерно по широте между Орлом и Курском (Vasmer 1932; Vasmer 1933). Следующей этапной работой в изучении «русской» доисторической Балтии стала книга В. Н. Топорова и О. Н. Трубачева (1962), посвященная гидронимии Верхнего Поднепровья. Правда, обследуемый в этой книге регион в основном приходится на территорию Украины и Белоруссии, а к России отходят лишь самые верховья Днепра и части бассейнов его крупных левосторонних притоков - Сожи, Десны и Сейма (Смоленская, Брянская и Курская области). Главная заслуга авторов в том, что они впервые выделили огромный, насчитывающий нескольких сотен единиц, массив водных имен, свидетельствующий о плотном заселении доисторическими балтами всего верхнеднепровского пространства, обрисовали примерный ареал балтийского этноязыкового слоя и его пересечения с пограничными финским и иранским слоями.

Книга 1962 г. интенсифицировала изучение субстратной гидронимии в странах Восточной Европы. Главный, определяющий вклад внес опять же В. Н. Топоров, поставивший задачу последовательного выявления древнебалтийского слоя на русских землях. Основное внимание он уделил бассейну Оки, прежде всего Верхнему Поочью и Подмосковью, а также Верхнему Поволжью, а с 1990-х гг. обратился также и к новгородско-псковским землям (многочисленные труды автора на гидронимическую тему перечислены в Завьялова, Цивьян 2014: 22-23). В своих содержательных статьях автор обстоятельно интерпретировал многие сотни русских гидронимических балтизмов. Гидронимические исследования Топорова отличаются широтой охвата исследуемых водных имен, обилием соотносимого с ними балтийского ономастического материала, глубиной и обстоятельностью этимологического анализа. Большинство трактовок водных имен в качестве балтизмов, изложенных в трудах этого автора, вполне убеждают, но, конечно, не все (что естественно при работе с столь большим массивом названий во многих регионах). Автор склонен трактовать вероятные балтизмы по максимуму и не всегда учитывает в достаточной мере следы не-балтийских языков (особенно языков прибалтийско-финских), данные русской диалектологии, вариантность и микросистемное окружение гидронимов. Как правило такие огрехи вскрываются только при тщательном внутрирегиональном (но не межрегиональном!) исследовании. Например, в статье (Топоров 1999) к вероятным гидронимическим балтизмам Новгородско-Псковского региона, среди прочих, отнесены Валдайка, Вельгуя, Волдомица, Лидь, Луга, Мда, Мста, Оредеж, Реполка, Ситенка, Ситня, 
Тросна, Солонииа, Болдырька, Деденька, Шлино, Шлина, Шлинеи, Шлинка (с. 280-282). Однако часть гидронимов из данного перечня обнаруживает соответствия в Финляндии, Карелии, на Русском Севере и Северо-Востоке, где балты не жили (Валдайка, Вельгуя, Волдомица, Лидь, Луга, Мда, Мста, Оредеж, Реполка), некоторые являются очевидными фактами славянского происхождения (Ситенка, Ситня, Тросна - это многочисленные славянские имена речек, поросших ситой и тростой, трестой, т. е. водными растениями, Солоница соотносится с рус. диал. соло́ной 'соленый'), другие объяснимы через русские названия прибрежных деревень (р. Болдырька названа по д. Болдыри: к прозвищу Болдырь, ср. русскую фамилию Болдырев; р. Деденька - по д. Дедно, буквально «Дедово»), либо через смежные гидронимы внутри одного водного бассейна (среди Шлино, Шлина, Шлинеи, Шлинка только одно водное имя балтизм, остальные появились вторично, благодаря переносу этого балтизма).

Гидронимические изыскания приводили к периодическим ревизиям границ «русской» доисторической Балтии. Если К. Буга в начале 1920-х гг. не распространял балтийский слой за пределы русских верховьев Днепра, Сожи и Западной Двины (смоленские и торопецкие земли), то П. Дини, суммировав итоги работ перечисленных выше авторов, в обобщающем труде «Балтийские языки» (Дини 2002) обрисовал ареал балтизмов, сложившийся, по его мнению, в последние века до н. э. - первые века н. э.: на севере граница этого ареала начинается возле Риги и идет слабоволнистой линией на восток к оз. Селигер в истоках Волги, от Селигера на восток до юго-восточных окрестностей г. Тверь, далее поворачивает на юг, проходит по западному предместью Москвы к верховьям рек Оки и Сейма, затем поворачивает на юго-запад, к Киеву, проходит через северные окрестности Киева на запад к украинской Волыни. Данная схема «максимального» ареала, сложившаяся в 1980-е гг., казалось, уже не изменится, так, А. Н. Топоров, имея в виду именно эту конфигурацию балтийского ареала, не продолжавшуюся далее правобережных притоков Верхней Волги, Верхнего и отчасти Среднего Поочья до Москвы, писал, что «к северу, востоку и югу нахождение надежных гидронимических балтизмов или очень сомнительно, или носит случайный характер» (Топоров 1988: 155). Однако очерченные ареальные границы стали пересматриваться в 1990-е гг., и к настоящему времени схема, обрисованная П. Дини, безусловно устарела.

Сначала самим же Топоровым был расширен за пределы Поочья южный фланг ареала, благодаря обнаружению нескольких десятков сравнительно достоверных балтизмов в верхнем течении Дона (Дриска, Деготенка, Сосна, Доробинка, Пальня, Матыра, Ведуга, Скобенка, Малейка и др.). Следовательно, границы балтийской гидронимии на данном участке «отодвигаются на 300-400 верст к югу» (Топоров 1997: 316).

Наряду с этим южным расширением, существенно пересматривалась восточная граница балтийского пространства. В ряде статей Ю. В. Откупщикова (1989; $2001 ; 2004)$ ареал гидронимических балтизмов от широты Москвы был отодвинут далеко на восток - до широты Нижнего Новгорода и Мордовии (до самых ни- 
зовьев Оки и до верховий рек Мокши и Теши, нижних правобережных притоков Оки). Автор - признанный специалист в области индоевропейской этимологии, много занимавшийся и реконструкциями лексики балтийских языков и связями их со славянскими языками. Однако он редко обращался к собственно ономастическим исследованиям и, на наш взгляд, излишне прямолинейно использовал методику этимологизации нарицательной лексики в трактовке гидронимии. Разберем более подробно, можно ли доверять гидронимическим этимологиям Ю. В. Откупщикова. Очевиден тот факт, что множество нижнепоочских водных имен, совершенно без сомнений, коротко и безапелляционно прокомментированных автором как балтизмы, на самом деле допускают либо более приемлемые объяснения из славянских или финно-угорских языков, либо их «балтийскость» нуждается в более развернутых доказательствах. Заявив, что «этимологизация, базирующаяся только на апеллятивной лексике, - малодоказательна» (Откупщиков 2004: 85), автор уповает на цельнолексемные попарные сопоставления современной гидронимии Литвы (редко Латвии) и Нижнего Поочья. Сравниваются изолированно взятые факты из регионов, отстоящих друг от друга более чем на тысячу километров, но игнорируются возможности сопоставления гидронимов с ономастическим и апеллятивным материалом соседних смежных языков (волжскофинские, прибалтийско-финские) или родственных языков (русский). Практически не учитывается то обстоятельство, что предположительно родственные гидронимы двух совсем разных регионов - Литвы и Нижнего Поочья - должны были разнонаправленно изменить свой фонетический облик за прошедшие одну, две или три тысячи лет их сосуществования в различавшихся языковых средах: они фонетически удалялись не только от породивших их апеллятивов (стремясь к т. н. «утрированной знаковости», по О. Н. Трубачеву), но и испытывали процессы фонетической и морфологической адаптации, субституции звуков в иноязычном окружении, иногда переосмысления и подгонки фонетических оболочек под иные апеллятивы и др. Гидроним Вад р. в Нижнем Поочье сближен с Vadas, Vada, реки в Литве, хотя водные имена Вад, Кузь-Вад, Лопьювад, Вадъёль, Вадма, Митя-Вад, Вадкерос, Вадыб и т. п. широко распространены по Русскому Северо-Востоку и в Северном Поволжье (связывают с коми вад 'озеро'). То же самое касается «балтизма» Шакща (автор сравнивает его с лит. Šakšélè), но рядом есть марийск. шокшо 'рукав реки' (и там еще р. Шокшовка) или даже коми шакша 'грязь'. Гидроним Вилка в бассейне Мокши приравнивается к лит. p. Vilka (: vilkas 'волк'), но не принимается в расчет, что восточные славяне должны были адаптировать эту родственную основу в виде Волк-, равно как и то, что основа Вил- со значением 'извилистый' повсеместно повторяется в собственно русской гидронимии: Вилея, Вилейка (: рус. диал. виле́йка 'извилина'), Вилица, Вилка, Вильня и т.п. Нижнепоочское Сарга р. приравнивается к лит. Sarg-upé, лтш. Sargupis (возможно, к sargas 'сторож'), но данное название скорее ожидалось бы с восточнославянским полногласным рефлексом (*Sarg- > ${ }^{*}$ Cорог-) при том, что в некоторых других случаях автор этот полногласный рефлекс учитывает. В нижнепоочских Аpmyc, Киструс, Углус видит морфологически не адаптированные 
балтизмы-апеллятивы, с сохранением даже флексии (!) литовского адъектива (к лит. artus 'близкий', kaistrus 'горячий', auglus 'пышный' - о растительности) при том, что водные имена на -yc, -ос характерны для европейско-финского пространства. Названия рек Рог, Старка, самоочевидно совпадающие с рус. диал. рог 'речной изгиб, мыс', ста́рка, ста́рица 'заглохшее речное русло', автор, тем не менее, объединяет с лит. Rag-upis (: ragus 'крутой'), Stark-upis (: starkas 'судак'). Название р. Нерль объяснено по лит. neris ‘бобр' (наряду с р. Neris в Литве), но в литовском это обозначение бобра ('ныряльщик') более позднего происхождения сравнительно с bebras, babras при том, что широкое проявление древней основы $n e r-$ и в индоевропейском, и в финно-угорском этноязыковом пространстве давно уже доказано (ср. сев.-рус. Неро, Нерехта, Нерома и др.). Автор не учитывает этноисторического контекста: трактуя гидронимы на бывшей мерянской территории, название поочской р. Мерка он сближает не с этнонимом меря, а с лит. merkti 'мочить, лить' и с Merke р. в Литве; название поочской р. Курша сравнивает с западнобалтийским этнонимом kuršis 'курши’ и р. Kuršs-upis, хотя следы западнобалтийского народа куршей вряд ли стоит ожидать в столь отдаленном месте Поволжья неподалеку от Нижнего Новгорода. Особенно большую методическую ошибку делает Ю. В. Откупщиков в тех случаях, когда применяет принцип системности к анализу нижнепоочской гидронимии, а именно пытается этимологизировать поочскую гидронимию в рамках типовых балтийских словообразовательных моделей. Данный подход позволяет «поставить на поток» этимологизацию гидронимии, но при этом совершенно упускается из вида, что продуктивные балтийские модели, как правило, омонимичны славянским (русским) моделям, и не замечается, что на балтийский манер анализируются явно русские или (реже) финно-угорские названия. Так, учитывая продуктивность балтийского (литовского) суф. -yn(as), дающего регулярные производные (типа marka 'яма, пруд для вымачивания льна' + -yn- = markinas 'сырой, влажный'), Откупщиков безоглядно подгоняет к данной модели множество нижнепоочских водных имен на -ин, -инской (например, ручьи, овраги и острова, называемые Маркин, Алкин, Белин, Кунин, Лунин, Палкин, Шляпин, Лапин, Кишкин, Мишкин, Паршин, Щедрин и др., Мыликинской, Полутинской, Петинской и др.), на -инка, -енка (реки Шилинка, Юдинка, Арининка, Крупинка, Сусенка и др.). С балтийским суф. -ок он мыслит гидронимы Навалок (= лит. nuovalus 'чистый' + суф. -ok-), а также Масток, Дубок, Валок, Ленок, Громок, с балтийским суф. -š- рассматривает речные названия рек Мокша, Лакша, Солодша и т.п., балтийский суф. -ој- видит в названиях рек Грезная, Дерная, Лютая, Спорная, Талая и т.п. Почти все перечисленные гидронимы без особого труда (и с явной необходимостью!) объяснимы на материале русской антропонимии и диалектной лексики, а некоторые имеют характерный исход -кша, -кса финно-угорских водных имен.

К сожалению, подобные трактовки крайне сомнительных «балтизмов» в работах Ю. В. Откупщикова имеют настолько массовидный характер, что не позволяют говорить о сколько-нибудь значимом проявлении балтийского гидронимического пространства в регионе Нижнего Поочья и Среднего Поволжья. Если ве- 
рить данным фактам, то можно прийти к выводу, что в Нижнем Поочье гидронимия еще «более балтийская», нежели в Верхнем Поочье и Верхнем Поднепровье. Конечно, и в данном регионе, весьма удаленном от современной Прибалтики, вероятны находки гидронимических балтизмов, хотя бы в дисперсном состоянии, появившихся как результат рассеивания из более западных регионов, или даже оставленных разрозненными группами балтов. Но чем дальше мы отступаем от центра «русской» доисторической Балтии, тем более основательными должны быть доказательства, найдены пусть единичные, но безусловно надежные, «маячковые» балтизмы и абсолютно убеждающие калькированные названия, метонимически соотнесенные с балтизмами. Пока на сегодняшний день наличие балтийских следов в низовьях Оки и в Среднем Поволжье нами ставится под сомнение. Лишь немногочисленные следы (Вобля, Дрисела, Дугна, Вепрея, Блиденка и др.) изредка находят не далее восточных районов Московской области (примерно до широты места впадения р. Москвы в р. Оку).

Поиски древнебалтийского элемента далеко к востоку от Москвы вели и другие исследователи, но, на наш взгляд, без особых успехов. Балтийскую гидронимию в междуречье Оки и Волги искал Ф. И. Гордеев, у которого (гидронимы Вылиа, Вьясс, Карнай, Уфа, Штырма, Стерля и др.) «многое ошибочно или малоубедительно» (Топоров 1972: 218). Б. А. Серебренников (1957) без достаточных оснований высказывал предположение, что в Волго-Окском междуречье обитало древнее индоевропейское население с языком, близким к балтийскому. В. В. Напольских (2006), опираясь на выводы археологов об Именьковской культуре IV-VII в. н.э. в Среднем Поволжье - Нижнем Прикамье, выдвигает гипотезу об особом балто-славянском «именьковском языке» носителей данной культуры в Волго-Камском регионе. Гипотеза поддерживается примерно десятком слов в пермских языках данного ареала (обозначения ржи, спорыньи, гуся, гриба, горы и др.), которые автор считает заимствованными из особого «именьковского языка», хотя они допускают и иные этимологии. При этом местная топонимия и гидронимия не анализируется, а ведь именно этот источник, а не апеллятивные заимствования, и есть главный маркер древнего языка (диалекта) в любом регионе.

Начиная с 1990-х гг. подвергся существенному пересмотру северо-восточный фланг ареала «русской» Балтии. Работы Р. А. Агеевой (1989: 185-208), В. Н. Топорова (1995: 13-40; 1999: 276-285; 2001: 7-22) и В. Л. Васильева (2007; $2008)$ позволили отодвинуть доисторическую балтийскую границу от Южной Псковщины и правобережья Верхней Волги, какой она традиционно принималась по трудам М. Фасмера, К. Буги, А. И. Соболевского, на несколько сотен километров к северу - вплоть до Финского залива Балтийского моря. На сегодня эта северо-восточная граница представлена линией, которая отходит на восток от Финского залива немного севернее устья р. Луги, пересекает р. Волхов в среднем течении (севернее г. Чудово, в окрестностях г. Кириши), идет далее к г. Тихвин, г. Бокситогорск Ленинградской области и к западной границе Вологодской области, где поворачивает на юг и через среднее течение р. Мологи спускается к г. Бежецк и г. Кимры Тверской области (см. рис. 1). Проведенное нами обстоятель- 


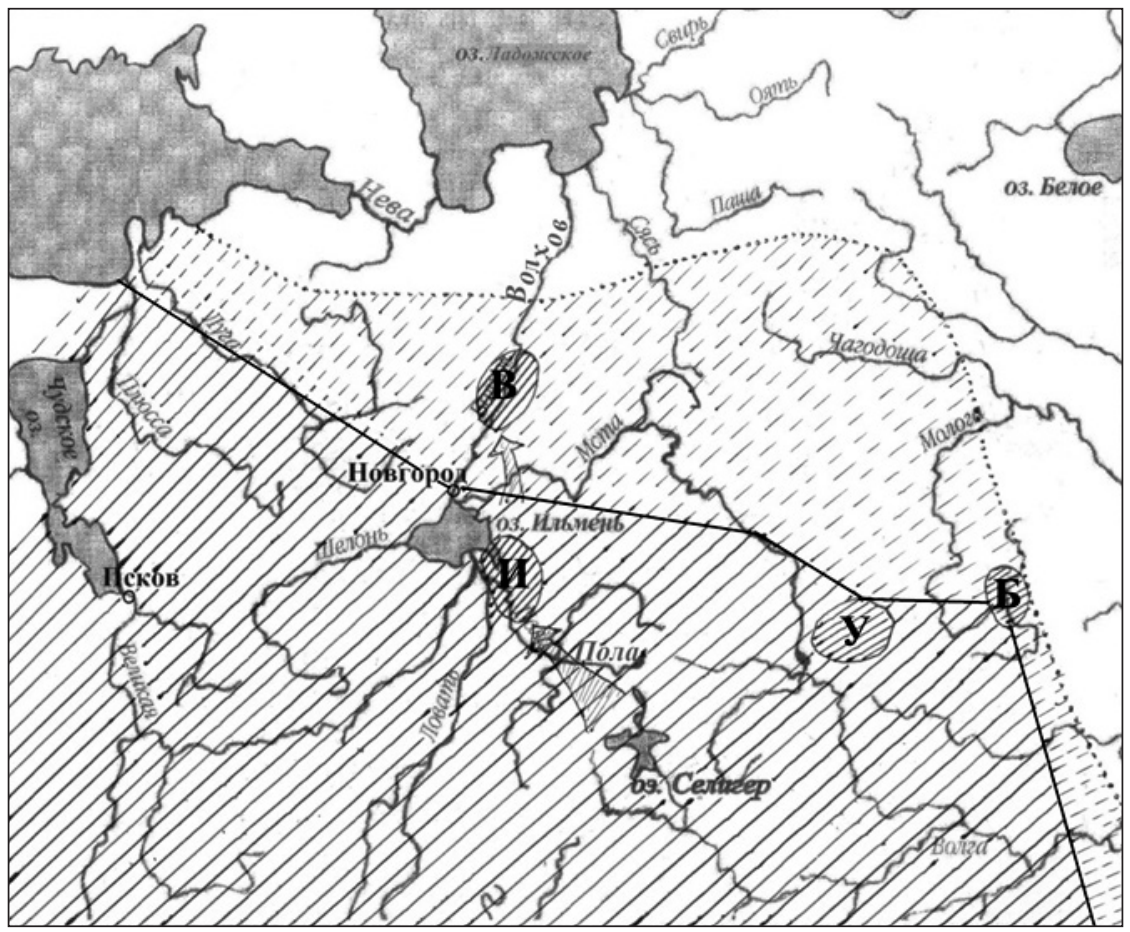

Рис. 1. Северо-восточный фланг ареала балтийской гидронимии.

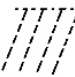

- схематизированная граница тах (максимального распространения на север, северо-восток и восток балтийской гидронимии)

П77 - условная линия $\min$ (количественного преобладания балтийского гидронимического элемента над финно-угорским)

पP

- преимущественный путь проникновения древних балтов на Ильмень и Волхов

- выявленные балтийские анклавы (явные скопления балтийских названий):

Б - Бежецкий, В - Волховский, И - Ильменский, У - Удомельский

ное, «внутреннее» обследование Новгородско-Псковского региона выявило различную плотность гидронимических балтизмов в данном регионе смешанного финско-балтийского субстрата. На территории южнее условной линии г. Нарва - г. Луга - г. Новгород - г. Боровичи - г. Удомля - г. Бежецк гидронимические балтизмы по количеству и по надежности трактовок обыкновенно преобладают (иногда в несколько раз) над гидронимическими финнизмами. Севернее этой линии общий гидронимический фон становится преимущественно прибалтийско-финским. В разных субрегионах, связанных с бассейнами местных рек, бал- 
тийский слой предстает с различной степенью очевидности, например, в верховьях р. Луги он более заметный, чем в бассейне р. Шелони, протекающей южнее, в бассейне р. Полы безусловно более плотный, чем в среднем и нижнем течении Ловати (до широты г. Холм). Выявлены несколько выраженных сгустков (анклавов) балтийской гидронимии: 1) на Волхове к северу от Новгорода, 2) в юго-восточных окрестностях оз. Ильмень, 3) в окрестностях Удомли, 4) в окрестностях Бежецка. Балтизмы связаны как с крупнейшими реками региона (Ловать, Пола, Полисть, Полометь, возможно, Шелонь, Волхов), так и с маленькими речками и ручьями длиной до десятка километров и озерами площадью несколько гектаров, помимо водоемов, встречаются балтийские названия селений (Яжелбицьь, Ловасицы, Вдаль, Цемена и др.).

Максимальный восточнославянский ареал балтийской гидронимии в том виде, в каком он суммируется по заслуживающим доверия работам, отражен на рис. 2. Удельная плотность балтийского слоя на этом огромном пространстве, которое в несколько раз больше территории современных Латвии и Литвы, различна. Применительно к России балтийские названия вод наиболее выражены в верховьях Днепра, включая бассейн Сожи, верхние течения рек Великой, Ловати, бассейн р. Полы, верховья Волги (до Твери), Верхнее и Среднее левобережное Поочье со включением бассейна р. Москвы. Однако суждения об удельном весе балтизмов сугубо предварительны, ибо поиск их далеко не завершен и велся он разными авторами в разное время, не в сплошном порядке, а по отдельно взятым регионам. Разумеется, различен и возраст балтийских гидронимов в России. У отдельных имен он может, вероятно, достигать 4 тыс. лет и более ввиду того, что археологи прослеживают в среднерусской полосе следы индоевропейских культур с III-II тыс. до н. э. К эпохе бронзы, преимущественно ко II тыс. до н. э., относят культуры т. н. «шнуровой керамики», прежде всего фатьяновскую и среднеднепровскую, которые обычно связывают с протобалтийским населением, для эпохи железного века I тыс. до н. э. - конца I тыс. н. э. отмечают соотносимые с балтами «городищенские» культуры (штрихованной керамики, днепро-двинскую, юхновскую, верхнеокскую), балтийский компонент находят в дьяковской культуре (наряду с финским), равно как в более поздних культурах смоленско-полоцких и псковско-новгородских длинных курганов 2-й половины I тыс. до н.э. (Булкин, Герд, Лебедев, Седых 1999: 270-276). Конечно, вполне вероятно закрепление многих гидронимических балтизмов и во II тыс. н. э., учитывая, что балтоязычная голядь в Поочье фиксируется даже в XIII в., что часть западнорусских земель до XVIII в. была тесно связана с литовским (позднее польско-литовским) государством, что в XIX в. было немало переселенцев из Прибалтики на русские земли (например, во 2-й половине XIX в. многие латыши переселились в Псковскую и Новгородскую губернии).

Дальнейшее изучение балтийского слоя требует не столько уточнения границ его ареала, сколько верификации уже выявленных в этом ареале гидронимических балтизмов на степень достоверности их «балтийскости», а также поиска новых достоверных балтийских гидронимов (и - шире - топонимов). Для оптимиза- 


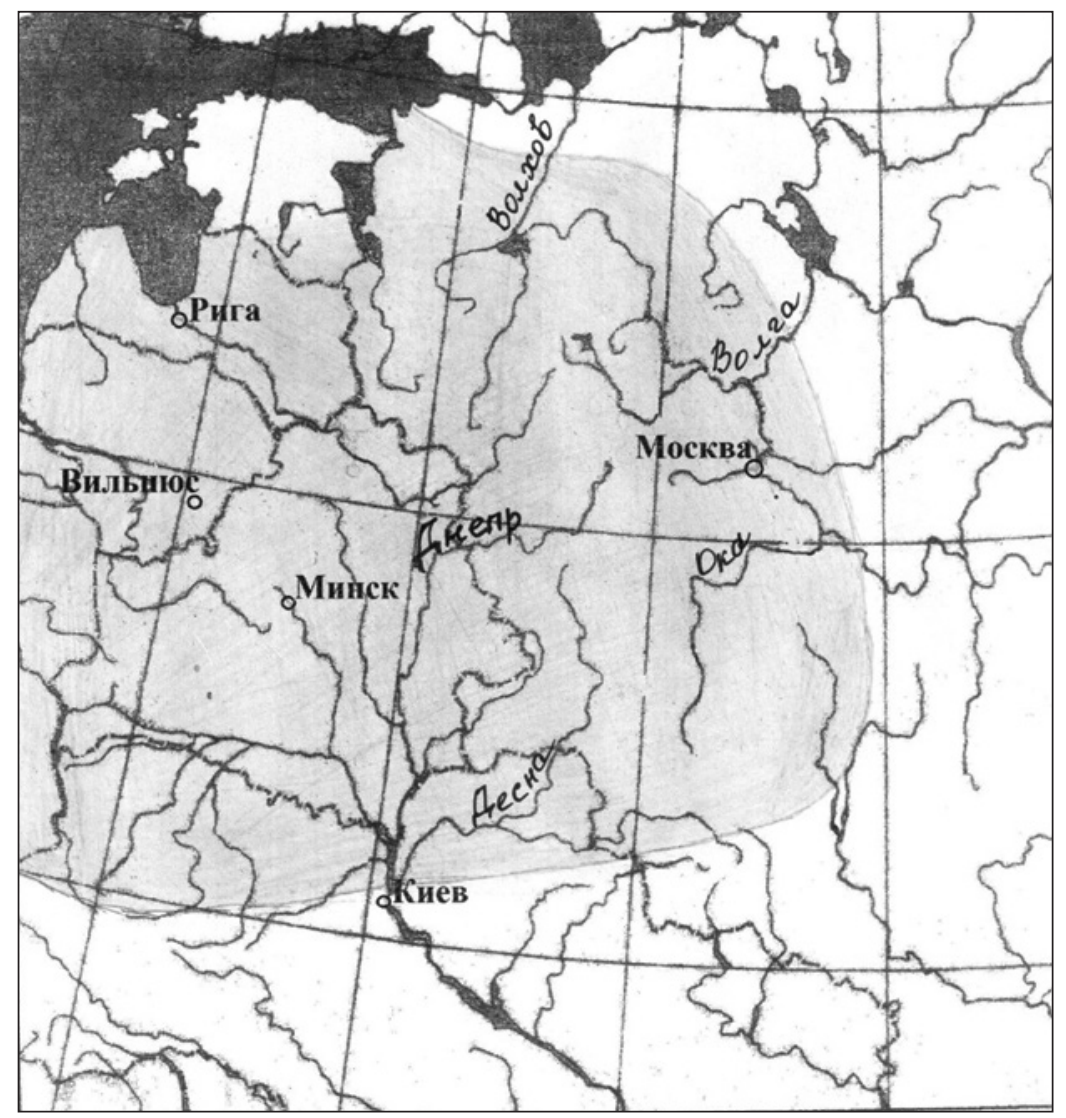

Рис. 2. Максимальный ареал балтийской гидронимии в восточнославянских землях.

ции общей методики определения балтизмов имеется пара возможностей, почти не реализованных на сегодняшний день.

Во-первых, сегодня необходим более широкий ареальный критерий. Для атрибуции гидронимии балтийского происхождения недостаточно наличия соответственных названий и апеллятивов в литовских, латышских, прусских землях, дополненных соответствиями в пределах показанного выше ареала; такая утвердительная «внутрибалтийская» атрибуция должна дополнительно подтверждаться отсутствием убедительных параллелей и эквивалентов за пределами балтийского ареала, к северу, востоку и югу от него, в пространных субстратных ареалах древнего проживания финно-угров, иранцев и других народов, где балтов априори ожидать не стоит. Если обнаруживаются внешне допустимые соответствия одновременно в двух или трех непересекающихся этноисторических пространствах (например, в балтийском и финно-угорском), то такие факты неопределенной этноязыковой принадлежности не могут считаться убедительными балтизмами, 
равно как и те факты, которые вообще пока не имеют ни надежно трактуемых связей, ни этимологии.

Во-вторых, не стоит увеличивать процент балтизмов за счет славянской топонимической архаики. В силу значительной близости славянского и балтийского языков в I тыс. н. э. многие водные имена проблематично дифференцировать на балтийские и славянские даже при очевидности их этимологии. Это прежде всего относится к слабо изученному слою позднепраславянских диалектизмов, отраженных гидронимией. Но как правило глубокий всесторонний анализ тех названий, которые на первый взгляд вполне допускают балтийские трактовки, часто открывает новые возможности более убедительного объяснения их как славянских топонимических архаизмов. Например, водные имена Березай, Бологое, Велья, Вельё, Вилейка, Велейка, Веребья, Веть, Витка, Водоса, Волма, Витьба, Выдерка, Дубна, Желонка, Колодея, Колпинка, Круппа, Линенка, Лопанка, Лоша, Лютейка, Меглинка, Орлинка, Песно, Плюсса, Полонка, Радча, Северка/Сиверка, Туренка, Тушемля, Уча, Череменецкое, Черенка и др., неоднократно повторяющиеся на Русском Северо-Западе и в других регионах и ранее объясненные или предварительно помеченные исследователями как балтизмы, оказалось предпочтительнее отнести к древнеславянскому слою (Васильев 2012: 616). Ничего не добавляет к изучению балтийского слоя также желание трактовать в качестве балтизмов (сильно обрусевших или переосмысленных) сравнительно поздние русские (древне-, старо- и современно-русские) названия, которые в подавляющем большинстве атрибутируются более надежно как славизмы, поскольку легко объясняются на славянском диалектном апеллятивном материале, многократно повторяясь в разных регионах России и других славянских стран.

\section{Литература}

BUGA, Kazimieras (1923) «Upių vardų studijos ir aisčiu bei slavenu senovè.» Tauta ir žodis. 1, 1-44.

BUGA, Kazimieras (1961) Rinktiniai raštai, 3. Vilnius: Politinès ir mokslinès literatūros leidykla.

VASMER, Max (1932) «Beiträge zur historischen Völkerkunde Osteuropas. I. Die Ostgrenze der baltischen Stämme.» Sitzungsberichte der Preussischen Akademie der Wissenschaften (philos.-hist. Klasse), 3-32.

VASMER, Max (1933) «Balten und Finnen im Gebiet von Pskov.» Studi baltici 3, 27-34.

АГЕЕВА, Руфь А. (1989) Гидронимия Русского Северо-Запада как источник культурно-исторической информации. Москва: Наука.

АНИКИН, Александр Е. (2005) Опьт словаря лексических балтизмов в русском языке. Новосибирск: Наука.

АНИКИН, Александр Е. (2014) «Проблемы изучения балтизмов в русском языке.» В: Сибирский филологический журнал 4, 189-195. 
БУЛКИН, Василий А./Александр С. ГЕРД/Глеб С. ЛЕБЕДЕВ/Валерий Н. СЕДЫХ (1999) Основания регионалистики: Формирование и эволюиия историко-культурных зон Европейской России. Санкт-Петербург: изд-во С.-Петербургского ун-та.

ВАСИЛЬЕВ, Валерий Л. (2007) «Древнебалтийская топонимия в регионе Новгородской земли.» В: Новгород и Новгородская земля: история и археология. Великий Новгород: Новгородский государственный объединенный музей-заповедник, 271-285.

ВАСИЛЬЕВ, Валерий Л. (2008) «О проблеме древнебалтийского топонимического наследия на Русском Северо-Западе.» Вопросы языкознания 3, 76-94.

ВАСИЛЬЕВ, Валерий Л. (2012) Славянские топонимические древности Новгородской земли. Москва: Рукописные памятники древней Руси.

ДИНИ, Пьетро У. (2002) Балтийские языки. Москва: ОГИ.

ЗАВЬЯЛОВА, Мария В./Татьяна В. ЦИВЬЯН (2014) «Balto-slavica в научном наследии В. Н. Топорова: перспективы.» В: Балты и славяне: пересечения духовныхх культур. Vilnius: Versmè, 13-31.

НАПОЛЬСКИХ, Владимир В. (2006) «Балто-славянский компонент в Нижнем Прикамье в сер. І тыс. н. э.» Славяноведение 2, 3-19.

ОТКУПЩИКОВ, Юрий В. (1989) «Балтийские гидронимы Мордовии.» В: Всесоюзная научно-практическая конференция «Исторические названия и памятники культуры». Москва: Наука, 67-68.

ОТКУПЩИКОВ, Юрий В. (2001) «О балтийской гидронимии бассейна Оки.» В: Ю. В. Откупщиков, Opera philologica minora (Античная литература. Языкознание). Санкт-Петербург: Наука, 363-365.

ОТКУПЩИКОВ, Юрий В. (2004) «Древняя гидронимия в бассейне Оки.» В: Балто-славянские исследования. ХVI. Сборник научных трудов. Москва: Индрик, 83-114.

ПОГОДИН, Александр Л. (1901) Из истории славянских передвижений. Варшава.

СЕРЕБРЕННИКОВ, Борис А. (1957) «О некоторых следах исчезнувшего индоевропейского языка в центре Европейской части СССР, близкого к балтийским языкам.» Труды Академии наук Литовской ССР, А, 1 (2). Вильнюс.

СОБОЛЕВСКИЙ, Алексей И. (1924) Русско-скифские этюды. Ленинград: Рос. Гос. Акад. тип.

ТОПОРОВ, Владимир Н. (1972) «Baltica Подмосковья.» В: Балто-славянский сборник. Москва: Наука, 217-280.

ТОПОРОВ, Владимир Н. (1988) «Балтийский элемент в гидронимии Поочья. І.» В: Балто-славянские исследования 1986. Москва: Наука, 154-177.

ТОПОРОВ, Владимир Н. (1995) «О северо-западнорусском локусе балтийской гидронимии (из цикла «По окраинам древней Балтии»).» Res Balticae 1, $13-40$.

ТОПОРОВ, Владимир Н. (1997) «Балтийские следы на Верхнем Дону.» В: Балтославянские исследования 1988-1996. Москва: Наука, 311-324. 
ТОПОРОВ, Владимир Н. (1999) «Балтийский элемент в Новгородско-Псковском ареале (общий взгляд).» В: Великий Новгород в истории средневековой Европы. К 70-летию В. Л. Янина. Москва: Русские словари, 276-292.

ТОПОРОВ, Владимир Н. (2001) «К вопросу о «новгородско-литовском» пространстве и его языковой характеристике (по материалам XIII-XV веков).» Res Balticae, 7, 7-22.

ТОПОРОВ, Владимир Н./Олег Н. ТРУБАЧЕВ (1962) Лингвистический анализ гидронимов Верхнего Поднепровья. Москва: изд-во Академии наук СССР.

\section{Аннотация \\ ПРОБЛЕМАТИКА ИЗУЧЕНИЯ ГИДРОНИМИИ БАЛТИЙСКОГО ПРОИСХОЖДЕНИЯ НА ТЕРРИТОРИИ РОССИИ}

В статье поднят широкий круг вопросов, связанных с отражением гидронимией России древнего присутствия балтов. Вся восточная половина обширного древнебалтийского этноисторического ареала приходилась на регионы Европейской России. Названия рек и озер - главный источник, позволяющий судить об их древнем расселении и некоторых особенностях их диалектного языка. Данная работа содержит обзор истории изучения гидронимии балтийского происхождения на территории России, включая критику отдельных предшествующих работ, и кратко освещает ряд вопросов, среди которых: 1) уточнение юго-восточных, восточных и особенно северо-восточных границ древнебалтийского ареала, 2) соотношение балтийского слоя с финским и иранским языковыми элементами, 3) отношение балтийской гидронимии к археологическим культурам, локализуемым в Европейской России, 4) оценка сравнительной плотности балтизмов по разным русским регионам, 5) оптимизация методики поиска и обоснования гидронимии балтийского происхождения. К статье приложены карты-схемы: 1) северо-восточного фланга ареала балтийской гидронимии, 2) максимального восточнославянского ареала балтийской гидронимии.

Ключевые слова: древнебалтийская гидронимия, российские регионы, этническая история балтов, ареал

Abstract

THE PROBLEMS OF STUDYING THE BALTIC ORIGINS OF HYDRONYMS ON THE TERRITORY OF RUSSIA

The article raises a wide range of issues related to the ancient presence of Balts in Russian hydronymy. The entire eastern half of the vast Old Baltic ethno-historical area overlapped with regions of European Russia. The names of rivers and lakes are the main source that allows to ascertain the extent of their ancient settlement as well as some features of their language. This paper provides an overview of the history of the 
study of hydronyms of Baltic origin on the territory of Russia, including the criticism of certain previous works, and briefly highlights a number of issues, among which are: 1) the refinement of the South-eastern, Eastern and especially North-eastern borders of the Old Baltic range, 2) the correlation of the Baltic linguistic elements with the Finnish and the Iranian elements, 3) the relationship of Baltic hydronymy to archaeological cultures, localizable in European Russia, 4) the relative density of the Baltic stratum in different Russian regions, 5) the optimization of techniques related to searching and confirmation of Baltic water names. Maps are provided to show the North-eastern flank of the Baltic hydronymic areal and the maximum geographical extent of Eastern Baltic hydronymy.

Keywords: Old Baltic hydronymy, Russian regions, ethnic history of the Balts, areal

\section{Povzetek \\ PROBLEMATIKA PROUČEVANJA HIDRONIMIJE BALTSKEGA IZVORA NA OZEMLJU RUSIJE}

Članek se dotika širokega kroga vprašanj, povezanih z nekdanjo prisotnostjo Baltov, kot se kaže v hidronimiji Rusije. Celotna vzhodna polovica obširnega starobaltskega etnozgodovinskega areala je ležala na območju Evropske Rusije. Imena rek in jezer so glavni vir, ki omogoča sklepanje o njihovi nekdanji poselitvi in nekaterih posebnostih njihovega narečnega jezika. Pričujoča obravnava vsebuje pregled zgodovine raziskav hidronimije baltskega izvora na ozemlju Rusije, vključno s kritiko posameznih prejšnjih del, in na kratko osvetljuje vrsto vprašanj, med katerimi so: 1) določitev jugovzhodnih, vzhodnih in še zlasti severovzhodnih meja starobaltskega areala, 2) razmerje baltske plasti do finskega in iranskega jezikovnega elementa, 3) razmerje baltske hidronimije do arheoloških kultur, ki so lokalizirane v Evropski Rusiji, 4) ocena relativne gostote baltizmov po različnih ruskih območjih, 5) optimizacija metodike prepoznavanja in utemeljevanja hidronimije baltskega izvora. Članku sta priloženi shematični karti: 1) severovzhodnega krila areala baltske hidronimije, 2) maksimalnega vzhodnoslovanskega areala baltske hidronimije.

Ključne besede: starobaltska hidronimija, ruske regije, etnična zgodovina Baltov, areal 